Wiestaw Ptywaczewski

\title{
NISZCZENIE DZIEDZICTWA KULTUROWEGO - MIĘDZY IMPERATYWEM EKONOMII I EKOLOGII. KRYMINOLOGICZNE UJĘCIE PROBLEMU Z PERSPEKTYWY WOJEWÓDZTWA WARMIŃSKO-MAZURSKIEGO
}

\section{Ochrona dziedzictwa kultury - uwarunkowania krajowe i międzynarodowe}

Niezwykle pojemna i wieloaspektowa dziedzina prawnej ochrony zabytków korzysta z bogatej i nie do końca spójnej terminologii. Wprawdzie obowiązująca od 2003 r. ustawa o ochronie zabytków i opiece nad zabytkami jednoznacznie opowiedziała się za uznaniem prymatu terminu ,zabytek”, jednakże w wielu innych aktach prawnych, korespondujących ze wspomnianą problematyką, spotkać można różne pojęcia w zależności od rozpatrywanego kontekstu. ${ }^{1} \mathrm{I}$ tak, na tle owej mozaiki terminologicznej funkcjonuje eksponowany przez uchyloną już ustawę z 1962 r. ${ }^{2}$ termin „,dobro kultury”. W rozważaniach na temat ekonomicznej strony działalności artystycznej pojawia się pojęcie ,dzieło sztuki”. Natomiast w piśmiennictwie poświęconym problemom polskiego muzealnictwa spotkamy termin „muzealia”, ,spuścizna narodowa” czy też „skarby narodowe”. Innym często używanym w literaturze przedmiotu terminem jest też ,dziedzictwo kultury”. Z racji swojej merytorycznej pojemności to właśnie pojęcie stanowić będzie podstawę niniejszych rozważań.

Najkrócej można je zdefiniować jako materialny i duchowy dorobek danej grupy społecznej. Zamiennie jest ono także określane w literaturze jako spuścizna kulturalna lub tradycja kulturowa (kulturalna) ${ }^{3}$. W języku prawnym pojęcie dziedzictwo kultury pojawia się w preambule do Konstytucji Rzeczypospolitej Polskiej. ${ }^{4}$ Mówi się w niej „o kulturze zakorzenionej w chrześcijańskim dziedzictwie narodu

Zob. K. Zeidler, Prawo ochrony dziedzictwa kultury, Warszawa 2007, s. 21-70.

Tekst jedn. Dz.U. z 1999 r. Nr 98, poz. 1150 z późn. zm.

Szeroko na ten temat - J. Pruszyński, Dziedzictwo kultury Polski. Jego straty i ochrona prawna, t. I, Kraków 2001, s. 42 i n.

$4 \quad$ Dz.U. z 1997 r. Nr 78, poz. 483. 
Niszczenie dziedzictwa kulturowego - między imperatywem ekonomi i ekologii...

i ogólnoludzkich wartościach oraz o zobowiązaniu, by przekazać przyszłym pokoleniom wszystko, co cenne z ponad tysiącletniego dorobku". Ponadto w art. 5 Konstytucji podkreśla się, iż Rzeczpospolita Polska strzeże dziedzictwa narodowego, wpisując to zadanie do zasadniczych kierunków działania państwa. Dodatkowo w art. 6 ust.1 ustawy zasadniczej stwierdza się, iż Rzeczpospolita Polska stwarza warunki upowszechniania i równego dostępu do dóbr kultury, będącej źródłem tożsamości narodu polskiego, jego trwania i rozwoju. W nawiązaniu do tej ustawowej deklaracji należy podkreślić, że dziedzictwo narodowe (w tym kulturowe) wraz z językiem i historią narodu kształtuje tożsamość narodową.

Dziedzictwo kultury można podzielić na dziedzictwo materialne i niematerialne. Podział ten jest zbieżny z powszechnie stosowaną terminologią zakładającą istnienie kultury duchowej i materialnej narodów. Do dziedzictwa materialnego zaliczane są wszelkie materialne przejawy kulturowej twórczości człowieka, zarówno nieruchomości, jak i rzeczy ruchome. Natomiast na dziedzictwo niematerialne składają się w szczególności takie elementy jak tradycja, obyczaje, poglądy, religia, język, historia, dziedzictwo sztuki, wartości patriotyczne (w tym godło, flaga i hymn) itd. $^{5}$

Dziedzictwo kultury można ujmować z perspektywy lokalnej, narodowej, regionalnej lub globalnej ( światowej). Coraz częściej rozpatrywane jest również jako dobro narodów zamieszkujących dany kontynent. Stąd często mówi się o dziedzictwie kultury europejskiej, afrykańskiej, czy na przykład dziedzictwie Aborygenów - rdzennych mieszkańców Australii. W ujęciu globalnym pojęcie to występuje jako światowe dziedzictwo kultury lub światowa spuścizna kulturalna. ${ }^{6}$

Potrzeba wypracowania skutecznych instrumentów prawnych w dziedzinie ochrony dóbr kultury stanowiła zasadniczy powód, dla którego społeczność światowa, za pośrednictwem swoich przedstawicieli, przyjęła w Paryżu w 1972 roku założenia „Konwencji w sprawie ochrony światowego dziedzictwa kulturalnego i naturalnego". ${ }^{7} \mathrm{Na}$ tle dotychczasowego dorobku międzynarodowego prawa publicznego był to jeden z pierwszych aktów prawnych ujmujących całościowo środowisko kulturowe i przyrodnicze, uznając je tym samym za wspólne dziedzictwo ludzkości. Należy zauważyć, że również wcześniejsza Konwencja Haska z 1954 r., odnosząca się wprawdzie do ochrony dóbr kultury w czasie konfliktu zbrojnego, zwraca uwagę na potrzebę ochrony dziedzictwa kulturalnego całej ludzkości. ${ }^{8}$

5 J. Pruszyński, Dziedzictwo kultury Polski..., s. 42-72.

$6 \quad$ H. Nieć, Ojczyzna dzieła sztuki. Międzynarodowa ochrona integralności narodowej spuścizny kulturalnej, Warszawa-Kraków 1980, s. 93 i n.

7 Dz.U. z 1976 r. Nr 32, poz. 190.

8 Dz.U. z 1957 r. Nr 46, poz. 212. 
Ważnym instrumentem ochrony tego dziedzictwa jest przewidziana w Konwencji Paryskiej z 1972 r. Lista Światowego Dziedzictwa Kultury UNESCO. ${ }^{9}$ Prawne podstawy utworzenia Listy daje Konwencja UNESCO z 1972 roku w sprawie ochrony światowego dziedzictwa kulturalnego i naturalnego (Dz.U. z 1976 r. Nr 32, poz. 190 i 191). Tekst tej konwencji został przyjęty w Paryżu na 16 sesji Konferencji Generalnej UNESCO. Po ratyfikowaniu jej przez 20 państw konwencja weszła w życie w 1975 roku. Natomiast pierwsza sesja Komitetu Światowego Dziedzictwa, który decyduje o wpisaniu danego obiektu na Listę, miała miejsce w Paryżu w 1978 r. Obecnie jej sygnatariuszami jest 176 państw. Pierwszy wpis na Listę obją 12 obiektów, w tym dwa z Polski - zespół staromiejski Krakowa i kopalnię soli w Wieliczce. Przepisy wykonawcze do tej konwencji zawiera dokument - „, Operational Guidelines for the implementation of the World Heritage Convention" . Określone zostały w nim obowiązujące kryteria i warunki wpisu, założenia dotyczące ochrony obiektów Światowego Dziedzictwa, formularze wniosku o wpis i zasady obowiązujące przy stosowaniu znaku Światowego Dziedzictwa. Przepisy konwencji z 1972 r. określają także obowiązek sporządzania raportów o stanie obiektów wpisanych na Listę („Periodal repords”). W myśl art. 1 konwencji za dziedzictwo kulturalne uważa się zabytki (dzieła architektury, dzieła monumentalnej rzeźby i malarstwa, elementy i budowle o charakterze archeologicznym, napisy, jaskinie i zgrupowania tych elementów mające wyjątkową, powszechną wartość historyczną, estetyczną lub naukową), 2) zespoły budowlane (budowle oddzielne lub łączne, które ze względu na swoją architekturę, jednolitość lub zespolenie z krajobrazem mają wyjątkową uniwersalną wartość historyczną), 3) miejsca zabytkowe (dzieła człowieka lub wspólne dzieła człowieka i przyrody, jak również strefy, a także stanowiska archeologiczne mające wyjątkową uniwersalną wartość z punktu widzenia historii, estetyki, etnografii lub antropologii).

O objęciu danego obiektu ochroną UNESCO w ramach Listy Światowego Dziedzictwa decyduje szereg kryteriów. Do końca 2004 r było sześć kryteriów dla obiektów dziedzictwa kulturowego i cztery dla przyrodniczego. W 2005 roku połączono je w jednorodną listę dziesięciu kryteriów. Obiekt kandydujący do wpisu na Listę musi przede wszystkim reprezentować ,unikatową uniwersalną wartość” oraz spełniać przynajmniej jeden z poniższych warunków. W przypadku obiektów kulturalnych wymaga się, aby odpowiadał on następującym kryteriom: 1) stanowił wybitne osiągnięcie twórczego geniuszu człowieka, 2) ilustrował znaczące oddziaływanie wartości w danej epoce lub w ramach danego kręgu kulturowego, w zakresie rozwoju architektury lub techniki, zabytkowej sztuki, planowania przestrzennego miast lub kształtowania krajobrazu, 3) wnosił unikalne lub co najmniej wyjątkowe świadectwo tradycji kulturowej bądź cywilizacji, żywej lub martwej, 4) stanowił wybitny 
Niszczenie dziedzictwa kulturowego - między imperatywem ekonomi i ekologii...

przykład rodzaju budowli bądź zespołu architektonicznego lub technicznego, który ilustruje znaczący etap w historii ludzkości, 5) stanowił wybitny przykład tradycyjnego sposobu osiedlania się lub zagospodarowania terenu, reprezentowany dla danej kultury (lub kultur), zwłaszcza kiedy miejsce narażone jest na wpływ nieodwracalnych zmian. Kryterium szóste ma charakter uzupełniający. Określa ono, że obiekt kulturalny winien łączyć się w sposób bezpośredni lub namacalny z wydarzeniami lub tradycjami żywymi, z ideami, wydarzeniami, z dziełami artystycznymi lub literackimi mającymi wyjątkowe uniwersalne znaczenie. Natomiast dotychczasowe kryteria przyrodnicze podkreślały, iż dany obiekt powinien: 1) obejmować wyjątkowe zjawiska przyrodnicze lub tereny szczególnego naturalnego piękna, 2) przedstawiać szczególne świadectwo ważnych etapów historii naszej planety, 3) przedstawiać szczególny przykład toczących się procesów ekologicznych i biologicznych, 4) obejmować najważniejsze środowiska przyrodnicze służące ochronie różnych form życia, zwłaszcza zagrożonych. Szczególne wytyczne odnoszą się do zespołów miejskich. Można je podzielić na trzy główne rodzaje: 1) miasta, które nie są zamieszkałe, ale przedstawiają niezmienne archeologiczne świadectwo przeszłości, 2) miasta historyczne zamieszkałe, rozwijające się pod wpływem zmian społecznokulturowych, 3) nowe miasta posiadające czytelny i niezaprzeczalnie autentyczny oryginalny układ miejski, wyróżniające się jednak dynamicznym tempem urbanizacji. We wszystkich wymienionych przypadkach kryterium podstawowym - decydującym o wpisie na Listę - będzie ocena autentyczności danego zespołu miejskiego.

Obecnie na Liście Światowego Dziedzictwa UNESCO znajduje się 878 miejsc w 145 krajach: 679 obiektów kulturalnych, 174 naturalnych i 25 o charakterze mieszanym kulturalno-przyrodniczym (stan na lipiec 2008 r.). Na Listę Dziedzictwa Zagrożonego („List of World Heritage in Danger”) wpisanych jest 30 miejsc. Zgodnie z art. 15 ust. 4 ustawy z dnia 23 lipca 2003 r. o ochronie zabytków i opiece nad zabytkami (Dz.U. Nr 162, poz. 1568) organem uprawnionym o wpis pomnika historii na Listę jest minister właściwy do spraw kultury i dziedzictwa narodowego. Adresatem takiego wniosku jest Komitet Dziedzictwa Światowego, który podejmuje decyzje o wpisie na dorocznej sesji (czerwiec/lipiec) w oparciu o rekomendację organizacji współpracujących z UNESCO. W przypadku dóbr kultury jest to Międzynarodowa Rada Ochrony Zabytków (ICOMOS), natomiast w spawach dotyczących obiektów przyrodniczych ocenę wystawiają eksperci Światowej Unii Ochrony Przyrody (IUCN). Lista informacyjna obejmująca obiekty zgłoszone przez dane państwo (z wyprzedzeniem do 10 lat) przedkładana jest Centrum Światowego Dziedzictwa (, UNESCO - World Haritage Center”) co najmniej na rok po wpisie na Listę informacyjną. Najkrótszy termin od momentu wysłania niezbędnej dokumentacji przez zgłaszające obiekt państwo wynosi półtora roku. Na Liście Światowego Dziedzictwa UNESCO w Polsce znalazły się: 1) zabytkowe centrum Krakowa (1978), 2) kopalnia soli w Wieliczce (1978), 3) niemiecki nazistowski obóz koncentracyjny 
i zagłady Auschwitz-Birkenau (1940-1945) w Oświęcimiu (1979), 4) Puszcza Białowieska (1979) - wspólnie z Białorusią, 5) historyczne centrum Warszawy (1980), 6) Stare Miasto w Zamościu (1992), 7) średniowieczny zespół miejski Torunia (1997), 8) zamek krzyżacki w Malborku (1997), 9) Kalwaria Zebrzydowska: manierystyczny zespół architektoniczny i krajobrazowy oraz park pielgrzymkowy z XVII w. (1999), 10) kościoły w Jaworznie i Świdnicy (2001), 11) drewniane kościoły południowej Małopolski - Binarowa, Blizne, Dębno Podhalańskie, Haczów, Lipnica Dolna, Sękowa (2003), 12) Park Mużakowski/ Muskauer Park nad Nysą - wspólnie z Niemcami (2004), 13) Hala Stulecia (Hala Ludowa) we Wrocławiu (2004). Miasta i obiekty z Polski, znajdujące się na Liście, skupione są w Lidze Polskich Miast i Miejsc UNESCO. Siedzibą tej inicjatywy jest Toruń.

Na mocy Zarządzenia nr 39 Ministra Kultury i Dziedzictwa Narodowego z dnia 30 października 2007 r. powołany został Komitet do spraw Światowego Dziedzictwa Kulturowego jako organ pomocniczy ministra. Głównym zadaniem Komitetu jest koordynacja prac i usprawnienie działań związanych z realizacją postanowień Konwencji UNESCO w sprawie ochrony światowego dziedzictwa kulturalnego i naturalnego z 1972 r. Obsługę administracyjną tego organu zapewnia funkcjonujący w strukturze Krajowego Ośrodka Badań i Dokumentacji Zabytków - Zespół ds. Światowego Dziedzictwa.

Ważnym składnikiem dziedzictwa kulturowego są pomniki historii. Powoływana wcześniej ustawa z dnia 23 lipca 2003 r. o ochronie zabytków i opiece nad zabytkami przewiduje w art. 15 ust.1-3 możliwość uznania zabytku za tego rodzaju pomnik. Może nim zostać jedynie zabytek nieruchomy oraz park kulturowy posiadający szczególną wartość dla kultury. Uznanie za pomnik historii następuje w drodze rozporządzenia Prezydenta Rzeczypospolitej Polskiej. W rozporządzeniu określa się granice terenów stanowiących pomnik historii. Prawo do składania wniosków w tym zakresie przysługuje ministrowi właściwemu do spraw kultury i dziedzictwa narodowego. Przed złożeniem wniosku musi on zasięgnąć opinii Rady Ochrony Zabytków. Cofnięcie uznania zabytku nieruchomego za pomnik historii następuje w trybie przewidzianym dla jego uznania W 2005 r. Rada Ochrony Zabytków przyjęła i zarekomendowała do stosowania następujące dokumenty: 1) „, Kryteria i procedury uznawania obiektu za Pomnik Historii”, 2) „Zasady tworzenia parku kulturowego, zarządzania nim oraz sporządzania planu ochrony”. Zgodnie z kryteriami przyjętymi przez Radę Ochrony Zabytków uznanie zabytku za pomnik historii jest wyjątkową formą wyróżnienia. Pomnikami historii mogą być tylko te zabytki nieruchome o znaczeniu ponadregionalnym, których wartość historyczna, naukowa i artystyczna ma szczególne znaczenie dla polskiego dziedzictwa kulturalnego. Ponadto muszą to być obiekty, które: 1) zachowały pierwotną kompozycję przestrzenną lub uległy nieznacznym przekształceniom, 2) są jednorodne stylowo lub posiadają czytelne i zharmonizowane nawarstwienia, 3) są właściwie wyeksponowane 
Niszczenie dziedzictwa kulturowego - między imperatywem ekonomi i ekologii...

w przestrzeni miejskiej lub w krajobrazie i zachowały pierwotne relacje z otoczeniem, 4) są dziełem wybitnych twórców (np. architektów, planistów, ogrodników), 5) są dobrze zachowane lub w stanie pozwalającym na ich rewaloryzację, 6) objęte są ochroną konserwatorską. Zatem pomnikami historii - zgodnie z przedstawionymi wyżej kryteriami, po spełnieniu szczegółowych wymogów określonych w wytycznych Rady Ochrony Zabytków - mogą być: krajobrazy kulturowe, układy urbanistyczne, ruralistyczne i zespoły budowlane, dzieła architektury i budownictwa lub zespoły tych dzieł o wspólnych cechach stylowych, użytkowych lub konstrukcyjnych, dzieła budownictwa obronnego, obiekty dziedzictwa przemysłowego, inżynierii lądowej i wodne, parki i ogrody, cmentarze, miejsca upamiętniające wydarzeń historyczne bądź związane z działalnością wybitnych osobistości lub instytucji oraz zabytki archeologiczne, które zaświadczają o dziejach osadnictwa. Szczegółowa procedura uznania zabytku za pomnik historii przewiduje następujące etapy podejmowanych czynności administracyjnych: 1) obiekt, zespół, układ przestrzenny lub obszar proponowany do uznania za pomnik historii musi być wpisany do rejestru zabytków lub objęty statusem parku kulturowego. Dla układów przestrzennych i obszarów winny być opracowane (i uchwalone) miejscowe plany zagospodarowania przestrzennego, 2) propozycję objęcia obiektu wyższą formą ochrony - uznanie za pomnik historii - wraz z właściwą dokumentacją (według obowiązującego wzoru), zgłaszający składa do Generalnego Konserwatora Zabytków za pośrednictwem i po zaopiniowaniu przez Wojewódzkiego Konserwatora Zabytków, 3) Departament Ochrony Zabytków MKiDN kieruje zgłoszenie do Krajowego Ośrodka Badań i Dokumentacji Zabytków (KOBiDZ) w celu zweryfikowania danych zawartych w dokumentacji i wydania opinii uzasadniającej propozycję uznania obiektu za pomnik historii, 4) zaopiniowane przez KOBiDZ zgłoszenie Minister Kultury i Dziedzictwa Narodowego przedkłada Radzie Ochrony Zabytków (zgodnie z jej kompetencjami, określonymi w art. 97 ustawy o ochronie zabytków i opiece nad zabytkami), 5) po wyrażeniu pozytywnej opinii przez Radę Ochrony Zabytków, Departament Ochrony Zabytków przekazuje dokumentację zgłoszenia do KOBiDZ, który przygotowuje projekt rozporządzenia Prezydenta RP wraz z uzasadnieniem i załącznikiem graficznym, 6) po dokonaniu analizy przez Departament Ochrony Zabytków projekt rozporządzenia Prezydenta RP przekazywany jest Ministrowi Kultury i Dziedzictwa Narodowego do ostatecznej akceptacji, 7) Minister kieruje wniosek o uznanie obiektu za pomnik historii do Prezydenta RP (wraz z dołączoną dokumentacją), 8) jeżeli wniosek uzyska akceptację urzędu prezydenckiego - Prezydent RP w drodze rozporządzenia uznaje obiekt za pomnik historii, określając jednocześnie jego granice. Rozporządzenie Prezydenta RP ogłaszane jest w „Dzienniku Ustaw”. Dotychczas za pomniki historii uznano 18 obiektów. Są to: 1) rezerwat archeologiczny Biskupin, 2) zespół klasztorny o.o. Paulinów na Jasnej Górze w Częstochowie, 3) zespół katedralny we Fromborku, 4) miasto Gdańsk w obrębie obwarowań z XVII w., 5) katedra p.w. Wniebowzięcia Najświętszej Marii Panny w Gnieźnie, 6) miasto Kazimierz 
Dolny, 7) historyczny zespół miasta Krakowa, 8) Krzemionki - kopalnie krzemienia z epoki neolitu we wsi Sudół, 9) zespół zamku krzyżackiego w Malborku, 10) wyspa Ostrów Lednicki na Jeziorze Lednickim we wsi Lednogóra, 11) Stare i Nowe Miasto w Toruniu, 12) historyczny zespół miasta Warszawy z Traktem Królewskim i Wilanowem, 13) kopalnia soli w Wieliczce, 14) historyczny zespół miasta Zamościa w obrębie obwarowań z XIX w., 15) historyczne centrum miasta Wrocławia, 16) kopalnia soli w Bochni, 17) Kalwaria - krajobrazowy zespół manierystyczny parku pielgrzymkowego w Kalwarii Zebrzydowskiej, 18) pole bitwy na Westerplatte w Gdańsku. Wśród obiektów oczekujących na uznanie za pomnik historii (posiadających pozytywną opinię Rady Ochrony Zabytków) znajdują się: 1) teren historycznej Bitwy Racławickiej, 2) podziemia zabytkowej kopalni rud srebronośnych oraz sztolnia „Czarny Pstrąg” w Tarnowskich Górach, 3) zespół klasztorny w Legnickim Polu, 4) zespół klasztorny o.o. Cystersów w Krzeszowie, 5) kompleks komponowanego krajobrazu kulturowo-przyrodniczego Góra Świętej Anny.

Minister właściwy do spraw kultury i dziedzictwa narodowego może przedstawić Komitetowi Dziedzictwa Światowego wniosek o wpis pomnika historii na Listę Dziedzictwa Światowego UNESCO w celu objęcia tego pomnika ochroną na podstawie konwencji w sprawie ochrony światowego dziedzictwa kulturalnego i naturalnego ${ }^{10}$

Potrzebę skutecznej ochrony dziedzictwa kulturalnego w polskim systemie prawa silnie akcentuje wspomniana już ustawa z 23 lipca 2003 roku o ochronie zabytków i opiece nad zabytkami (dalej powoływana jako - u.o.z.). W art. 6 ustawy wskazuje się, że opiece i ochronie podlegają, bez względu na stan zachowania, określone kategorie zabytków nieruchomych i ruchomych oraz zabytków archeologicznych. Są to w szczególności: a) krajobrazy kulturowe, b) układy urbanistyczne, ruralistyczne i zespoły budowlane, c) dzieła architektury i budownictwa, d) dzieła budownictwa obronnego, e) obiekty techniki (kopalnie, huty, elektrownie i inne zakłady przemysłowe), f) cmentarze, g) parki ogrody i inne formy zagospodarowania zieleni, h) miejsca upamiętniające wydarzenia historyczne bądź działalność wybitnych osobistości lub instytucji.

Natomiast zabytkami ruchomymi, zgodnie z postanowieniami u.o.z., są w szczególności: a) dzieła sztuk (plastycznych, artystycznych i użytkowych), b) kolekcje, c) numizmaty, d) pamiątki historyczne, e) wytwory techniki, f) określone materiały biblioteczne, g) instrumenty muzyczne, h) wytwory sztuki ludowej i rękodzieła, i) przedmioty upamiętniające wydarzenia historyczne.

Ważne jest, aby wymienione obiekty posiadały uznaną wartość historyczną, artystyczną lub naukową. W katalogu kryteriów mogą pojawić się również inne do- 
Niszczenie dziedzictwa kulturowego - między imperatywem ekonomi i ekologii...

datkowe wyznaczniki przyznawania danemu obiektowi ochrony prawnej, takie chociażby jak wartość patriotyczna, religijna czy estetyczna. Należy podkreślić, że szczególna ochrona prawna przewidziana jest dla tych zabytków, nieruchomych lub ruchomych, które zostały wpisane do rejestru lub ewidencji prowadzonej przez służby konserwatorskie. Nie oznacza to jednak, że pozostałe składniki dziedzictwa kultury, niefigurujące w dokumentacji konserwatorskiej, pozostają poza zainteresowaniem właściwych organów rządowych lub samorządowych. Zgodnie z wcześniej powoływanymi przepisami rangi konstytucyjnej, a także - stanowiącymi ich wypełnienie - regulacjami zawartymi w u.o.z., na organach tych ciąży ustawowy obowiązek dbania o wszystkie składniki dziedzictwa kultury. ${ }^{11}$

Z perspektywy podjętych w niniejszym artykule rozważań szczególnie ważne jest zapewnienie należnej ochrony prawnej historycznym zespołom urbanistycznym i ruralistycznym, budowlanym oraz krajobrazowi kulturowemu wraz z jego otoczeniem. Ochrona tych szczególnych obiektów zabytkowych została potwierdzona m.in. w Zaleceniu UNESCO przyjętym w Nairobi w 1978 roku, dotyczącym zespołów zabytkowych i tradycyjnych oraz ich roli w życiu współczesnym. Należy zaznaczyć, iż wspomniane zalecenie posługuje się pojęciem środowiska zespołów zabytkowych lub tradycyjnych, podkreślając tym samym specjalną więź zabytku i otaczającej go przestrzeni przyrodniczej. ${ }^{12}$ Warto $\mathrm{w}$ tym miejscu przypomnieć, że również wcześniejsze zalecenia UNESCO wyraźnie akcentują znaczenie harmonijnego funkcjonowania człowieka w środowisku naturalnym oraz potrzebę wzmożenia ochrony nad obszarami przyrodniczymi, w obrębie których zlokalizowane są cenne kompleksy zabytkowe. ${ }^{13}$ Bogata jest również działalność operacyjna UNESCO. Niewątpliwie do najbardziej znanych inicjatyw tej organizacji zaliczyć należy akcje ratowania zabytków Nubii, chodzi tu w szczególności o operacje ratowania niezwykle cennego kompleksu Abu Simbel w Egipcie. Nie mniejszy zasięg miały kampanie na rzecz ratowania Wenecji (do dziś kontynuowane), kompleksu świątyń buddyjskich w Borobudur (Indonezja), zabytków Mohejno Daro (Pakistan), a także zespołu świątyń w Angkor (Kambodża). Inicjatywy UNESCO na rzecz ratowania dóbr kulturalnych pozwalają wysunąć tezę, że solidarność państw, ich poczucie odpowiedzialności za

11 Tamże, s. 49.

12 W najnowszych regulacjach prawnych, odnoszących się do ochrony spuścizny kulturalnej, traktowanie problematyki ochrony dziedzictwa przyrodniczego (naturalnego) na równi z ochroną dziedzictwa kulturowego stało się już standardem.

13 Efektem tych zainteresowań były zalecenia Konferencji Generalnej UNESCO w sprawie ochrony piękna krajobrazu z 1962 roku. Zalecenia te ustalały, że ochrona ta polegać będzie na „zachowaniu, oraz, o ile to możliwe, odtwarzaniu naturalnych, tak wiejskich jak i miejskich cech pejzażu i miejsc, czy to naturalnych, czy stworzonych przez człowieka, jeżeli posiadają kulturalną i estetyczną wartość albo też jeśli tworzą typowe otoczenie naturalne." - szerzej na ten temat J. Pruszyński, Prawna ochrona zabytków architektury w Polsce, Warszawa 1977, s. $109-115$. 
losy światowej spuścizny kulturalnej tkwi nie tyko w prawnej płaszczyźnie, lecz również ma głębokie moralne uzasadnienie. ${ }^{14}$

Doniosłą rolę w zakresie ochrony europejskiego dziedzictw kultury odgrywa działalność prawotwórcza Wspólnot Europejskich. Pośród licznych aktów prawa wspólnotowego regulujących tę sferę na uwagę zasługują m.in.:

- zalecenie Komisji 75/65/EEC z dnia 20 grudnia 1974 r. dotyczące ochrony dziedzictwa architektonicznego i naturalnego, ${ }^{15}$

- rezolucja Rady z dnia 13 listopada 1986 r. o ochronie europejskiego dziedzictwa architektonicznego, ${ }^{16}$

- rezolucja Rady z dnia 13 listopada 1986 r. o konserwacji dzieł sztuki i zabytków, ${ }^{17}$

- wniosek Rady z dna 17 czerwca 1994 r. o nakreśleniu wspólnotowego planu działań na polu dziedzictwa kultury, ${ }^{18}$

- rezolucja Rady z dnia 12 lutego 2001 r. o jakości architektonicznej w środowisku miejskim i wiejskim. ${ }^{19}$

Niezwykle doniosłym aktem prawnym prawa wspólnotowego dotyczącym europejskiego dziedzictwa przyrodniczego jest również dyrektywa Rady 92/43/EWG z 21 maja 1992 r. w sprawie ochrony siedlisk przyrodniczych oraz dzikiej flory i fauny (tzw. dyrektywa siedliskowa - art. 4 ust. 1 dyrektywy siedliskowej i art. 4 ust. 2 dyrektywy ptasiej), która dała podstawę prawną dla stworzenia „Europejskiej Sieci Ekologicznej Natura 2000". Sieć ta stanowi specjalną formę ochrony przyrody realizowaną na terenie wszystkich państw członkowskich Unii Europejskiej. Celem utworzenia Sieci było zagwarantowanie ochrony najbardziej cennym przyrodniczo i krajobrazowo obszarom, na których znajdują się - wymagające specjalnej ochrony - siedliska roślin i ptaków i tym samym uniemożliwienie przemysłowej eksploatacji tych miejsc. Polska wyodrębniła 124 obszary specjalne ochrony ptaków oraz 364 specjalnych obszarów ochrony siedlisk ${ }^{20}$. Konkurencyjną listę stworzyły polskie organizacje ekologiczne. ${ }^{21}$ Przypadek Rospudy potwierdził, że w konflikcie między potrzebami gospodarczymi a dobrem środowiska człowieka, to właśszarów (obiektów) chronionych objętych ochrona specjalna, organizacja ta może wycofać swoje rekomendacje i skreślić dany obiekt z Listy Światowego Dziedzictwa Kultury.

Dz.Urz. UE 1975, L 21.

Dz.Urz.UE 1986, C 320.

Dz.Urz. UE 1986,C 320.

Dz.Urz. UE 1994, C 235.

Dz.Urz. UE 2001, C 73.

Zob. rozporządzenie Ministra Środowiska z 21 lipca 2004 r. w sprawie obszarów specjalnej ochrony ptaków Natura 2000 - Dz.U. Nr 229, poz. 2313 oraz z 2007 r., Nr 179, poz. 1275.

21

Zob. "Shadow list" - natura. 2000.mos.gov.pl/natura2000/pl/ 
nie ochrona tego ostatniego dobra powinna stanowić kryterium słuszności prawa. ${ }^{22}$ Istotnym składnikiem tego środowiska jest uporządkowane, harmonijne otoczenie. Według specjalistów od krajobrazu, ważne jest nie tylko to, co widzimy, ale również te wrażenia, które odbieramy przez inne zmysły, takie jak słuch, powonienie, dotyk. ${ }^{23}$ Nikt nie chce żyć na tle zdewastowanego krajobrazu. Ludzie uciekają ze ,złych dzielnic" do miejsc niedotkniętych degradacją społeczną i ekologiczną. Okazuje się bowiem, że nieskażony zgubnymi wpływami cywilizacji krajobraz jest najlepszą lokatą kapitału. Czystość i naturalność przyciągają turystów a także zachęcają do osiedlenia się.

Odpowiadając na postawione w tytule opracowania pytanie - czy można pogodzić interes ochrony dziedzictwa ludzkości zarówno kulturowego, jak przyrodniczego z interesami gospodarczymi, należy tytułem odpowiedzi przywołać tylko niektóre wybrane przykłady potwierdzające taką możliwość. Wymienić tu można m.in. łódzkie budowle historyczne (tzw.”lofty”) - „Manufakturę” oraz „Muzeum Miejskie", gdańską filharmonię - umiejętnie wkomponowaną w zabytkowy krajobraz miasta, czy też poznański „Stary Browar”. Obiekty te po gruntownej rewaloryzacji i modernizacji, nie tracąc nic ze swej historycznej atrakcyjności, pełnią jednocześnie funkcje handlowe bądź kulturalno-rozrywkowe.

Na tle tradycyjnego katalogu czynów zabronionych, godzących w dziedzictwo kultury, na pierwszy plan wysuwają się przede wszystkim przestępstwa skierowane przeciwko mieniu o wartości zabytkowej. Są to kradzieże, w różnych postaciach rodzajowych tego przestępstwa - kradzieże zwykłe, kradzieże rozbójnicze, kradzieże z włamaniem oraz rozboje. Na szczególną uwagę, o czym już wcześniej była mowa, zasługują te kategorie przestępstw, których istotą jest niszczenie. W praktyce przybierają one postać grabieży składników dziedzictwa kultury lub ich dewastacji, nierzadko połączonej z wandalizmem. Niniejszy przegląd przestępstw uzupełnić należy o przestępstwo przywłaszczenia, paserstwa oraz przemytu dóbr uznawanych za zabytki. ${ }^{24}$ Wymienione kategorie czynów zabronionych określone zostały w różnych aktach prawnych, zarówno w regulacjach karnych kodeksowych, jak również w obrębie tzw. pozakodeksowego prawa karnego. ${ }^{25}$ Należy zauważyć, że ów stan swoistego rozproszenia przepisów karnych w licznych i nie do końca spójnych ze sobą regulacjach prawnych znacząco utrudnia w praktyce ochronę dóbr kultury.

Por. K. Dziadosz, Racjonalność ekologiczna jako kryterium słusznego prawa, (w:) R. Sobański (red.), Prawa człowieka w państwie ekologicznym, Warszawa 1998. Także O. Cabaj, Środowisko naturalne człowieka pomiędzy prawem a ekonomia: casus doliny Rospudy, (w:) Człowiek pomiędzy prawem a ekonomia w procesie integracji europejskiej, red. G. Dammacco, B. Sitek, O. Cabaj, Olsztyn-Bari 2008, s. 448.

23 Zob. J. Ćwieluch, J. Podgórska, Quado-plaga. Przyroda nie wytrzymuje nowej rozrywki Polaków, Polityka 2009 , nr 20, s. 20-23.

24 Na ten temat - W. Pływaczewski, Handel dziełami sztuki z perspektywy przestępczości zorganizowanej, (w:) Człowiek pomiędzy prawem a ekonomią w procesie integracji europejskiej, red. G. Dammacco, B. Sitek, O. Cabaj, Olsztyn-Bari 2008, s. 724 i n. nr 11. 


\section{Perspektywa regionalna}

Dziedzictwo kulturowe Warmii i Mazur to zarówno historyczne siedziby wielkich rodów pruskich, dwory i pałace z przyległymi do nich ogrodami i parkami, jak również zabytkowe budynki folwarczne. ${ }^{26}$ Wiele z tych obiektów zostało zniszczonych w czasie II wojny światowej, inne padły ofiarą grabieży, podpaleń, a w końcu celowej lub bezmyślnej dewastacji spowodowanej przez późniejszych właścicieli. Taki los spotkał m.in. jedną z najokazalszych rezydencji rodowych w Kamieńcu k. Iławy (dawna siedziba rodu Finck von Finckenstein), wzorowanych na założeniach przestrzennych Wersalu. Rezydencja ta spłonęła w 1946 r. na skutek zaprószenia ognia przez stacjonujących tam żołnierzy radzieckich. W podobnych okolicznościach zniszczone zostały rezydencje w Słobitach i Gładyszach (ród zu Dohna) oraz Arklitach (ród Egloffsteinów). W opłakanym stanie znajduje się dawna posiadłość innego pruskiego rodu Lehndorffów w Sztynorcie, niegdyś miejsce spotkań europejskiej elity intelektualnej. ${ }^{27}$ Wielokrotnie bywał tu m.in. znakomity poeta, ówczesny biskup warmiński Ignacy Krasicki. Nie lepiej prezentuje się dawna siedziba rodu Donhoffów w Drogoszach. Ten wspaniały obiekt w stylu barokowym, przejęty przez prywatnego nabywcę, prawdziwa perła budownictwa pałacowego (jego projektantem był John von Collas), może w najbliższym czasie podzielić los unicestwionych już historycznych budowli. Na listę negatywnych przykładów traktowania pomników przeszłości wpisuje się również jedna z największych warowni gotyckich w Szymbarku, dawna siedziba biskupów pomezańskich, a później własność rodu Finckensteinów. ${ }^{28}$ Jego nabywca, oprócz podstawowych prac zabezpieczających, nie wykazuje chęci do wywiązania się z ustawowych zobowiązań deklarowanych wobec służb konserwatorskich, co - jak należy przypuszczać - wróży temu obiektowi smutną przyszłość.

Kolejnym przykładem braku właściwej troski o substancję zabytkową, a także swoistej inercji władz rządowych i samorządowych oraz organów ścigania odpowiedzialnych za stan zabytkowego mienia, jest los dawnego zamku krzyżackiego w Giżycku. ${ }^{29}$ Zmieniając co kilka lat właścicieli, zamek ten w międzyczasie uległ daleko zaawansowanemu procesowi niszczenia, co w konsekwencji doprowadziło do katastrofy budowlanej, polegającej na zawalenia się jednej z głównych ścian tej

Zob. M. Bartoś, B. Zalewska, Architektura w krajobrazie wiejskim Warmii i Mazur, Olsztyn 2007, s. 58 i n. W 2009 r. powołana została fundacja, której głównym celem jest przywrócenie do pierwotnego stanu tego cennego obiektu. Szerzej na ten temat - I. Liżewska (red.), Sztynort. Utracone dziedzictwo - czy szansa na ocalenie, materiały z konferencji z 5-6 listopada 2008 r., Fundacja „Borussia”, 2009 r.

W jego murach kręcone były sceny do głośnego filmu Volkera Schlondorffa „Król Olch”.

Paradoksalnie tzw. sprawa giżycka zmusiła władze konserwatorskie województwa warmińsko-mazurskiego do podjęcia w 2009 r. zdecydowanych działań wobec tych administratorów zabytkowych obiektów, którzy rażąco naruszaja przepisy ustawy o ochronie zabytków. 
Niszczenie dziedzictwa kulturowego - między imperatywem ekonomi i ekologii...

budowli. W ramach prowadzonego przez prokuraturę wieloletniego postępowania karnego nie ustalono winnych zaniedbań i sprawę umorzono. ${ }^{30}$

$\mathrm{Na}$ tle przytoczonych wybiórczo negatywnych przykładów stosunku do historycznej spuścizny kulturalnej, można i należy odwoływać się do tych przedsięwzięć, które nie tylko świadczą o szczególnej wrażliwości ich inicjatorów na problem ochrony zabytków, ale są również przykładami umiejętnego łączenia wymogów konserwatorskich z funkcjami komercyjnymi. Do nich niewątpliwie należy zaliczyć efekty prac rewaloryzacyjnych i rewitalizacyjnych podjętych w historycznej siedzibie komturów krzyżackich w Rynie. Obiekt ten był użytkowany, przed jego przejęciem przez nowych właścicieli - z różnym skutkiem - przez liczne instytucje publiczne i prawdopodobnie podzieliłby los innych tego rodzaju budowli. Obecnie zaadaptowany dla potrzeb wypoczynkowo-kongresowych z uwzględnieniem rygorystycznych zaleceń konserwatorskich, stanowi jedną z najokazalszych budowli tego typu w Europie. Jednocześnie zamek w Rynie wyrasta na ważny ośrodek krzewienia wiedzy historycznej (w tym konserwatorskiej), a także poprzez swoje walory architektoniczno-estetyczne i krajobrazowe, chociażby za sprawą organizowanego cyklicznie Festiwalu Kultury Średniowiecza „Masuria”, na centrum edukacyjne w zakresie kształtowania właściwych postaw wobec spuścizny kulturalnej w wymiarze wielokulturowym. Nie należy również zapominać, że tego rodzaju ośrodki, często zlokalizowane w małych miejscowościach, to ważny element gospodarczego ożywienia i zawodowego aktywizowania lokalnych społeczności dotkniętych zjawiskiem bezrobocia i ubóstwa oraz licznymi patologiami społecznymi.

Podobnym przykładem szczególnej dbałości o spuściznę zabytkową i jej przyrodnicze otoczenie jest obecny stan zespołu pałacowo-parkowego oraz folwarku w Galinach k. Lidzbarka Warmińskiego. Ta dawna siedziba pruskiego rodu Eulenburgów, wzorcowy przykład architektury rezydencjonalnej, na skutek zawieruchy wojennej, a później beztroskiej eksploatacji przez poszczególnych administratorów, była bliski zagłady. Dziś, za sprawą prywatnych inwestorów, odrestaurowany z wyjątkowym pietyzmem (prace te są kontynuowane), stanowi wzorcowy przykład łączenia oczekiwań służb konserwatorskich oraz ich umiejętnego powiązania z założonymi przez inwestorów celami ekonomicznymi. ${ }^{31}$ Odrestaurowane obiekty mieszczą pomieszczenia hotelowe, restaurację, stajnie, krytą ujeżdżalnię koni itd. Miejsce to, podobnie jak wspomniany wcześniej zamek w Rynie, wyrasta na liczą-

30 Warto zauważyć, że - niestety - ta forma zakończenia postępowania karnego przez organy prokuratorskie w sprawach dotyczących niszczenia obiektów nieruchomych o wartości zabytkowej stała się nagminną praktyka.

31 J. Pałyska, K. Pałyska, Założenia pałacowo-parkowe z folwarkiem w Galinach, (w:) Zachowane - ocalone ? O krajobrazie kulturowym i sposobach jego kształtowania, pod red. Iwony Liżewskiej i Wiktora Knercera, Olsztyn 2003, s. 165-171. 
cy się w skali kraju ośrodek wypoczynkowo-szkoleniowy, a także centrum konnej rekreacji. ${ }^{32}$

Przytoczone przykłady to zaledwie fragment tych przedsięwzięć, które wpisują się w narodowy i europejski program ratowania dziedzictwa kultury. Potwierdzają one jednocześnie, że zasada zrównoważonego rozwoju, polegająca na integrowaniu działań politycznych, gospodarczych i społecznych z zachowaniem równowagi przyrodniczej, znajduje swoje praktyczne potwierdzenie.

\section{Podsumowanie - propozycje}

Postępująca degradacja środowiska naturalnego człowieka na skutek gwałtownego rozwoju cywilizacyjnego implikuje szereg negatywnych zjawisk. ${ }^{33}$ Siłą rzeczy dotykają one również dziedzictwa kultury. Przede wszystkim obserwujemy proces zrywania ciągłości tradycji dziedzictwa kulturowego w środowiskach lokalnych. Procesowi temu towarzyszy jednocześnie zjawisko ignorowania przez planistów i architektów miejscowych uwarunkowań związanych z ochroną krajobrazu. Aby zapobiec tym negatywnym tendencjom, należałoby przede wszystkim ograniczyć tzw. dziką zabudowę. Chodzi o to, aby na tle krajobrazu mazurskiego czy podlaskiego nie pojawiały się chaty góralskie, i odwrotnie - abyśmy np. w Zakopanem nie oglądali ceglanych budowli w stylu gotyckim. Kolejne niebezpieczeństwo to groźba unifikacji realizowanych projektów budowlanych z uwagi na ich powtarzalność. W ten sposób powstaje nowy, monotonny i „bezduszny” krajobraz, w którym ludzie czują się wyalienowani z otoczenia i odarci z tradycji. Przeciwdziałać tym negatywnym zmianom można poprzez zachęcanie biur projektowych do opracowania projektów uwzględniających specyfikę kulturową poszczególnych mikroregionów (np. Warmii, Mazur, Podlasia, Kaszub) oraz poprzez propagowanie zasad kształtowania pojedynczych budynków i ich układów zgodnie z lokalną tradycją. Zasadne byłoby również opracowanie przez odpowiednie instytucje państwowe lub samorządowe szczegółowych wytycznych dla szczególnie cennych krajobrazowo i historycznie mikroregionów z uwzględnieniem wymagań konserwatorskich i przyrodniczych, aby zahamować proces zastępowania naturalnych surowców i materiałów budowlanych przez nowe, przeważnie nie ekologiczne produkty, które są obce miejscowej tradycji budowlanej. ${ }^{34}$ Przykład ,kultury sidingu” jest tu znamienny. Po latach okazało się bowiem, że tradycyjnie wznoszone drewniane chaty wiejskie, na skutek po-

W 2000 r. właściciele obiektu otrzymali Złoty Medal w konkursie Ministra Kultury i Dziedzictwa Narodowego za zorganizowanie i prowadzenie prac rewaloryzacyjnych w parku pałacowym w Galinach.

33 Zob. R. White, Crimes Against Nature. Environmental criminology and ecological justice, Willian Publishing 2008; także - P. Beirne and N. South, Issues in Green Criminology, Confronting harms against environments, humanity and other animals, Willian Publishing 2007. 
Niszczenie dziedzictwa kulturowego - między imperatywem ekonomi i ekologii...

krycia ich plastykową powłoką nie przepuszczającą powietrza, podlegają dziś niszczącym je procesom zawilgocenia. A zatem słuszny wydaje się postulat, aby w ślad za wspomnianymi wytycznymi wyodrębniane były regiony wyróżniające się walorami krajobrazowo-architektonicznymi i historycznymi, na których obowiązywałyby zaostrzone kryteria uzyskiwania zgody na modernizację zabytkowych budowli lub rozpoczęcie inwestycji. Na uwagę i popularyzację zasługują zwłaszcza propozycje zgłaszane przez Stowarzyszenie na Rzecz Ochrony Krajobrazu Kulturowego Mazur „Sadyba”. Organizacja ta od wielu lat przeciwdziała dewastacji mazurskowarmińskiego krajobrazu. Warto przypomnieć, że dzięki szybkiej interwencji członków tego stowarzyszenia powstrzymany został proceder niszczenia zabytkowych drzewostanów w województwie warmińsko-mazurskim. Swoją drogą zastanawiające jest, że dopiero społeczny sprzeciw wstrzymał bezmyślny wyrąb zabytkowych drzew i zmusił władze samorządowe do uwzględnienia argumentów ekologów. ${ }^{35}$ Wspomniana organizacja optuje też za szerszym niż dotychczas promowaniem pozytywnych przykładów ochrony dziedzictwa zabytkowego oraz wspiera wszelkie działania na rzecz kształtowania poczucia tożsamości regionalnej. Niezwykle pomocne w takich działaniach mogą być również inicjatywy wydawnicze, w tym różnego rodzaju praktyczne poradniki dla inwestorów i deweloperów, zawierające katalogi obiektów nawiązujących do tradycyjnego budownictwa danego regionu. ${ }^{36}$

Nie ulega wątpliwości, że ochrona dziedzictwa kultury stanowi istotny element tożsamości narodowej. Stąd niezwykle istotnym zadaniem wielu podmiotów odpowiedzialnych za nią jest przeciwdziałanie zjawiskom niszczenia, dewastacji i grabieży składników spuścizny narodowej. Postępujący pęd ku nowoczesnym formom w architekturze nie zawsze sprzyja zachowaniu tradycyjnych stylów w budownictwie. Ubocznym efektem owej - nie do końca przemyślanej - fascynacji nowoczesnością jest zjawisko nieuwzględniania ekologicznych uwarunkowań krajobra$\mathrm{zu}$, co w konsekwencji prowadzić może do jego nieodwracalnej degradacji. $\mathrm{Na}$ przykład jeszcze do niedawna w powszechnym odbiorze społecznym stare domostwa wiejskie uznawane były za dowód zacofania cywilizacyjnego. ${ }^{37}$ Wprawdzie ten stereotyp wolno przechodzi do przeszłości, jednakże następstwa takiego stosunku do pamiątek przeszłości są niestety nieodwracalne. Szansą na zachowanie resztek cennego dziedzictwa kulturowego, w tym w szczególności architektonicznego i krajobrazowego, jest m.in. rozwój turystyki. Umiejętne połączenie dawnych form zabudowy z wymogami współczesnej turystyki i rekreacji, co zostało wyżej przed-

35 K. Worobiec, Dbajmy świadectwo historii, Gazeta Wyborcza z 30-31 maja 2009 r., s. 2; także - I. Liżewska, Krzysztof A. Worobiec, Aleje przydrożne. Historia, znaczenie, zagrożenie, ochrona, Kadzidłowo - Olsztyn 2009.

$36 \quad$ I. Liżewska, Tradycyjne budownictwo..., s. 99 i n.

37 Jak potwierdzaja badania na temat wizerunku krajów europejskich (tzw. ranking Anholta), to co Polakom kojarzy się z zacofaniem, dla mieszkańców innych krajów stanowi niezwykle atrakcyjny turystycznie wyznacznik nietkniętej przyrody - zob. W. Smoczyński, Polska kraj bez twarzy. Raport, Polityka 2009, nr 27, s. 30-34. 
stawione, stanowi warunek zahamowania niebezpiecznych tendencji we wspomnianych obszarach, zaświadczających o stanie naszej kultury.

Reasumując, należałoby przede wszystkim zintensyfikować działania edukacyjne związane z popularyzacją problematyki ochrony dziedzictwa kultury. W pierwszej kolejności winny one być adresowane do młodzieży szkolnej, która w ramach wychowania obywatelskiego (ekologicznego) poznawać powinna problematykę dziedzictwa narodowego i europejskiego. ${ }^{38}$ Do tego rodzaju zajęć, prowadzonych przez doświadczonych pedagogów, zasadne byłoby również angażowanie przedstawicieli organów ścigania (prokuratorzy, policjanci), a także właścicieli wzorcowych obiektów historycznych.

Podobne projekty edukacyjne w formie szkoleń i warsztatów kierować należałoby do poszczególnych grup zawodowych odpowiedzialnych za stan ochrony dziedzictwa kultury. W pierwszej kolejności są to urzędnicy państwowi i samorządowi, na których z mocy prawa spoczywa obowiązek przeciwdziałania przestępczości i innym patologiom społecznym skierowanym przeciwko pamiątkom przeszłości i związanemu z nimi krajobrazowi. Ważnym ogniwem działań zapobiegawczych w tym zakresie są pracownicy nadzoru budowlanego oraz urzędów konserwatorskich, w tym także wojewódzcy konserwatorzy przyrody. Podobną rolę w tych działaniach odgrywać powinni planiści (zwłaszcza zajmujący się zagospodarowaniem historycznych przestrzeni) oraz architekci, inwestorzy i deweloperzy. Swoją drogą odrębne szkolenia powinny być kierowane do przedstawicieli organów ścigania i wymiaru sprawiedliwości. Okazuje się bowiem, że stan wiedzy przedstawicieli tych podmiotów, co potwierdzają liczne kontrowersyjne rozstrzygnięcia w sprawach dotyczących niszczenia dziedzictwa kultury, nie jest satysfakcjonujący. ${ }^{39}$

\footnotetext{
38 Od 1993 r. Stowarzyszenie Wspólnota Kulturowa „Borussia” realizuje program „Nowe Życie pod Starymi Dachami” oraz „Międzynarodowy wolontariat w ochronie krajobrazu kulturowego na Warmii i Mazurach.”

39 Por. W. Pływaczewski, Symptomy zagrożeń korupcyjnych na rynku dzieł sztuki, Przegląd Policyjny nr 3, z 2007, s. 15 i n.
} 


\section{SUMmARY}

In the article, the author discusses the problem of destruction of the cultural heritage, as seen from the perspective of criminology, economics, and ecology. The author explains the meaning of such basic terms as monument, cultural asset, and work of art. The term cultural heritage is discussed extensively with references to the Convention concerning the protection of the world cultural and natural heritage adopted in Paris in 1972, which established the UNESCO World Heritage List. The author discusses in detail the text of the convention and the related procedures. In reference to the Polish Act of 23 July 2003 on protection of monuments and care for historical relics, the author discusses the institution of "historical monument" and the conditions for its establishment. The discussion of the laws pertaining to the protection of the cultural heritage ends with the author's presentation of the legislative activity of the European Communities in this area. The author supplements his discussion of the subject with examples of depredation and devastation of cultural monuments in the Warmia i Mazury region of Poland. In the article's conclusion, the author presents a list of recommended preventive measures which, in his opinion, may help to stop the process of destruction of Poland's material and spiritual cultural heritage. 